\title{
Electronic Billing System
}

National Cancer Institute

\section{Source}

National Cancer Institute. Electronic Billing System. NCI Thesaurus. Code C52655.

A computer-based tracking and submission system for statements, bills, invoices, and related information corresponding to the payment for goods or services. 